\title{
Determination of stress in the geological medium on the basis of deep well data using acoustoelastic correlations
}

\author{
H. H. Guliyev, K. B. Aghayev, G. A. Sultanova, 2019 \\ Institute of Geology and Geophysics of Azerbaijan National Academy of Sciences, \\ Baku, Azerbaijan \\ Received 11 July 2019
}

\begin{abstract}
Розроблено метод визначення нормальних компонентів тензора напружень в деформованих геологічних середовищах на основі баз даних геофізичних досліджень глибоких свердловин. Те-оретичною основою методу є акустичні співвідношення некласичного лінеаризованого підходу нелінійної еластодинаміки. Отримано аналітичні формули розрахунку напружень в геологічному середовищі у випадках малих і великих деформувань. Використано дані геофізичних досліджень свердловин, розташованих в Південнокаспійському басейні. Складено тонкошаруваті одновимі-рні моделі середовища за швидкостями поширення поздовжніх і поперечних хвиль, щільностю та літологією порід. Товщина кожного шару моделей становить кілька сантиметрів, який дорів-нює кроку спостережень за розрізом свердловини. Аля врахування впливу зміни термобаричних умов геологічного середовища на акустичні властивості порід дані кожної моделі, що відносяться до однієї і тієї ж літології поріА, розчленовані на кластери з застосуванням штучних нейронних мереж. За моделями Аля кожної літології порід і кластера даних розраховано значення модулів пружності 2-го і 3-го порядків і нормальних компонент тензора напруження. Виявлено, що пружні модулі 3-го порядку набагато чутливіші до мінливості пружних властивостей середовища, ніж модулі 2-го порядку. Отримані чисельні результати за всіма кластерами кожної літології по-рід усереднені. При цьому кількість шарів середовища по кожному кластеру даних використано як ваги. А при осереднені результатів за всіма породами, як ваги використано кількість шарів середовища за кожною породою. Вивчено залежності між чисельними значеннями нормальних компонент тензора напруження, що спричинені геостатичним тиском, і аналогічними величинами, викликаними геодинамічними змінами відповідного компонента тензора напруження. Вияв-лено, що напруження, зумовлені геостатичним тиском, істотно нижчі, ніж напруження, зумов-лені геодинамічними змінами. Отримані акустичні формули дають змогу визначити напруження в геологічному середовищі будь-якого регіону з урахуванням впливу сучасних геодинамічних процесів.
\end{abstract}

Ключові слова: акустичні співвідношення, напруження, модуль пружності, пружні хвилі, геофізичне дослідження свердловин, кластер даних.

Introduction. The non-classically linearized approach (NLA) of nonlinear elastodynamics [Abasov et al., 2000; Alexandrov et al., 2001; Vyzhva et al., 2005; Guliyev et al., 2011, 2016; Guliyev, 2018b] has found wide use in researches of various problems of modern geodynamics and seismic exploration. The basis of this approach is the study of the prop- agation of elastic waves in the pre-stressed media [Biot, 1965; Guliyev, Dzhabbarov, 1998; Guz, 2004; Akbarov, 2015; Guliyev et al., 2018; Guliyev, 2018a]. The use of the NLA allows bringing complex nonlinear problems of dynamics to well-studied linear problems by non-classical linearization (linearization is not carried out in a small neighborhood of the un- 
deformed state and in a small neighborhood of the current state in contrast to the classical theory of elasticity and linear waves). In this case, all nonlinearities are included in the coefficients of the equation of motion in disturbances as known functions or parameters.

The use of the NLA in tasks of processing and interpretation of results of well-logging operations (WLO) [Guliyev et al., 2016] and seismic explorations [Guliyev et al., 2011] allow obtaining new quantitative results for the kinematic and dynamic parameters of elastic waves [Guliyev, Dzhabbarov, 1998], finding out the reason to obtain large and negative values of Poisson's ratio [Guliyev, 2000] in studies of problems of seismic explorations. It is shown [Guz, 2004] that experimentally observed effects in compressible concerning rigid materials in the theory are well described in case of involving elastic potentials of the Murnaghan type and using "true» velocities. Therefore, the use of the NLA in problems of geophysics, seismology, in particular seismic exploration requires a preliminary determination of elasticity moduli of the third order along with the linear physical and mechanical properties of the geological medium that characterize nonlinear deformation. The experimental results of these rocks are almost absent for rocks of the sedimentary series [Bayuk et al., 1988]. Exceptions make up results [Bakulin, Protoseniya, 1982; Yin, Rasolofosaon, 1994; Alexandrov et al., 2001; Guliyev et al., 2016]. A theoretical method based on database of wells is proposed for their determination to fill this gap [Guliyev et al., 2016].

The influence of initial stress on the nature of the propagation of elastic waves in rocks and sands has been experimentally studied [Li, Tao, 2015; Teachavorasinskun, Pongvithayapan, 2016]. Another interesting variant of study of effects of initial stress is suggested [Tromp et al., 2019]. The main linear and nonlinear physico-mechanical properties of the geological medium, the kinematic parameters of elastic waves, and the main components of the stress tensor are analytically related to each other in acousto-elastic correlations in the NLA. The values of the principal components of the stress tensor are determined considering different options of the theory of initial deformation using these correlations and database created [Guliyev et al., 2016] in this manuscript.

The proposed approach fundamentally differs from the existing approaches of determination of paleostress based on focal mechanisms of earthquakes [Balakina et al., 1972; Reinecker et al., 2005; Aghayeva, Babayev, 2008]. It is known that the type of stress state is approximately determined using the principles [Gintov, 2005; Anderson, 2007] on type of fracture in this approach. At the same time, the stress-strain state is characterized by the orientation of the main axes of normal stress. This approach is more acceptable if there are large fractures in the studied region. Nevertheless, the resulting deformation modes are conditional. These methods are good when there are data on the signs of the first arrivals of pressure waves for a large number of seismic stations for earthquakes with a magnitude of $M>4$. The advanced CASMO method is also used on the project of construction the World Stress Map [Reinecker et al., 2005; Müller et al., 2005]. At the same time, events are grouped using the so-called Composite Focal Mechanism (CFM) and single focal mechanism (SFM) [Heidbach et al., 2004].

Acoustic correlations obtained [Guz, 2004] in linear approximation (concerning acting stress) for compressible rigid isotropic bodies with an elastic potential of the Murnaghan type have been successfully applied in developing the basis of a non-destructive ultrasonic method to determine uniaxial and biaxial stress in solid bodies [Guz et al., 1974; Guz, 2004]. The method is based on laws of the propagation of elastic waves in compressible concerning rigid materials with initial stress applied to infinite bodies and intended for materials such as metals and alloys and for determining stress when its value is less than the durability limit.

This method is developed to determine quantitative values of basic components of stress tensor at the point of the geological medium, i.e. in local zones, which have the highest values in oil field geology during drilling and operation of wells. 
All modern geodynamic changes related to neotectonics, seismicity, the action of mud volcanoes, the fragmentation of separate blocks, the drilling of deposits, the intensity of hydrocarbon extraction, water injection and other tectonic impacts without exception are reflected in the velocities of elastic waves. Therefore, they are also taken into account while determining stress along with the influence of general tectonic processes.

Database. Thin-layered one-dimensional models (1D) are used on velocities of pressure and shear waves, density of rocks of data on lithological dismemberment of the geological medium while calculating the elasticity moduli as source data. The models are constructed according to data of well-logging operations of various types of two wells located in the South Caspian basin [Babayev, Gadzhiev, 2006]. Wells are highly oil and gas bearing. The depth interval of explorations on wells 1 and 2 is $600-3800 \mathrm{~m}$ and $2500-5800 \mathrm{~m}$ accordingly. Geophysical measurements in each well are made with a step of $10 \mathrm{~cm}$. This step is taken as the thickness of each layer of the medium. Layers with anomalous values of physical parameters arising due to technical reasons have not been used in the calculations while measuring well logging. The lithological section of the first well mainly consists of 5 types of sedimentary rocks. Codes of lithology of rocks are indicated: 1 - anhydride; 2 - green and gray argillite, shale, clay, compacted clay; 3 - brown argillite; 4 - sand; 5 - siltstone, silt [Guliyev et al., 2016]. The lithological section on the second well consists of 4 types of rocks: 1 - clay, argillite, schist; 5 - silt, siltstone; 7 - gypsum anhydride; 9 - sand, sandstone.

The distance between the wells is several tens of $\mathrm{km}$. The same stratigraphic boundary opened by these wells differs approximately $2200 \mathrm{~m}$ on depth. Therefore, the rocks of the same layers of the medium along these wells are in different temperature and pressure conditions. Therefore, the petrophysical properties of the same rocks along the wellbore differ significantly.

Further, some petrophysical features of rocks of the studied medium are considered according to well logging data 1 . The correlations between seismic velocities and density of rocks have been constructed (Fig. 1). Velocities of pressure $\left(V_{S}\right)$ and shear $\left(V_{S}\right)$ waves vary on the same types of rocks at constant value of density in a wide range.

The value of velocity, as well as its dispersion also increases due to increase of density. There are no univocal correlations between velocity and density.

The numerical values of $V_{S}$ and $V_{S}$ with variations increase due to increase of geostatic pressure (Fig. 2). It follows from the figure that values of velocities differ according to lithologies of rocks. It can be seen on the graph as a band of values of velocities at close values of pressure. Here, the dispersion of values of velocities on the pressure wave is greater than on the shear wave. It is due to the oil and gas content of rocks of separate layers of the medium. Thus, unlike the pressure wave, the velocity of shear wave almost doesn't depend on fluid saturation of rocks [Garotta, 2000].

Graphs show that correlations between the values of $V_{S^{\prime}} V_{S}$ and density differ significantly according to lithology of rocks and vary for rocks of the same lithology depending on the pressure in the medium. It should be noted that layers of the medium belonging to the same lithology actually differ in composition of rocks. Data are divided into clusters to consider these factors while calculating elastic properties of rocks of the same lithology. It allowed determining layers of the medium belonging to one and the same lithology which have similar laws on change of pethrophysical properties depending on the change of pressure.

Data on layers of the medium related to the same rocks are divided into 10 clusters using neural networks in this manuscript [Poulton, 2002; Chashkov, Valery, 2011]. Optimal values of parameters of clusterization have been determined by testing.

The values of Poisson's ratio, elasticity moduli of the 3rd order $a, b$ and $c$ are calculated using well logging data according to the method [Guliyev et al., 2016]. The nature of the distribution of values of moduli differs in 
well 1 and 2 significantly. The large dispersion of values of elasticity moduli along the wellbore mainly characterizes thin layering and strong contrast of elastic properties of the medium (Fig. 3, $a$ and 4, a). Comparison of dispersions of values of velocities, Poisson's ratio and moduli $a, b$ and $c$ show that elasticity moduli of the third order are much more sensible to variability of properties of the medium than moduli of the second order.

Values of moduli $a$ and $b$ have positive and negative values with high dispersion. Depths with positive values prevail in the module $a$ (Fig. $3, b$ ), and negative values in the module $b$ (Fig. 3, c). Similar nature of change of moduli values is observed on well 2 (Fig. $4, a, b$ ). Values of moduli $c$ are constant within each data cluster (Figs. 3, $c$ and 4, c). Values $c$ vary on clusters and rocks. Its value generally increases in depth. Such a nature of the elasticity moduli is observed according to the data of both wells.

Analysis of the used initial data on density of rocks, velocities of propagation of pressure and shear waves, Posson's ratio, elasticity moduli and $a, b$ and $c$ show that they have high quality. These data reliably characterize acoustic and elastic properties of the studied complexly constructed geological medium and are used to determine stress state further.

Basic calculation formulae. The basic kinematic parameters of propagating elastic waves in deformed media satisfy the following acoustoelastic correlations [Guz, 2004]:

$$
\begin{aligned}
& b_{1}=a_{11} \sigma_{11}^{0}+a_{12} \sigma_{22}^{0}+a_{13} \sigma_{33}^{0}, \\
& b_{2}=a_{21} \sigma_{11}^{0}+a_{22} \sigma_{22}^{0}+a_{23} \sigma_{33}^{0}, \\
& b_{3}=a_{31} \sigma_{11}^{0}+a_{32} \sigma_{22}^{0}+a_{33} \sigma_{33}^{0} .
\end{aligned}
$$

Based on these correlations of the NLA to calculate the basic components of the stress tensor we find:

$$
\begin{gathered}
\sigma_{11}^{0}=\frac{\left|A_{1}\right|}{\left|A_{0}\right|}, \sigma_{22}^{0}=\frac{\left|A_{2}\right|}{\left|A_{0}\right|}, \\
\sigma_{33}^{0}=\frac{\left|A_{3}\right|}{\left|A_{0}\right|},\left|A_{0}\right| \neq 0 .
\end{gathered}
$$

Where the following symbols are taken:

$$
\begin{aligned}
A_{0}=\left(\begin{array}{lll}
a_{11} & a_{12} & a_{13} \\
a_{21} & a_{22} & a_{23} \\
a_{31} & a_{32} & a_{33}
\end{array}\right), A_{1}=\left(\begin{array}{lll}
b_{1} & a_{12} & a_{13} \\
b_{2} & a_{22} & a_{23} \\
b_{3} & a_{32} & a_{33}
\end{array}\right), \\
A_{2}=\left(\begin{array}{lll}
a_{11} & b_{1} & a_{13} \\
a_{21} & b_{2} & a_{23} \\
a_{31} & b_{3} & a_{33}
\end{array}\right), \\
A_{3}=\left(\begin{array}{lll}
a_{11} & a_{12} & b_{1} \\
a_{21} & a_{22} & b_{2} \\
a_{31} & a_{32} & b_{3}
\end{array}\right) .
\end{aligned}
$$

Specific structures of elastic potentials should be set and forms of elastic oscillations («true» or «natural» velocities) should be selected [Guz, 2004] to carry out the calculations. The algebraic expressions have been obtained while using the "true» velocities, the theory of large initial deformations and the elastic potential of the Murnaghan type for the elements $a_{i j}$ and $b_{i}(i=1,2,3 ; j=1,2,3)$ determinants [Guz, 2004]:

$$
\begin{gathered}
a_{11}=2(\lambda+\mu)(2 \lambda+4 \mu+2 b+c)+ \\
+2(a+b) \mu+3 K_{0} \mu, \\
a_{12}=2(a+b) \mu-\lambda(2 \lambda+4 \mu+2 b+c), \\
a_{13}=2(a+b) \mu-\lambda(2 \lambda+4 \mu+2 b+c), \\
a_{21}=(\lambda+\mu)\left(1+\frac{C}{4 \mu}\right)+b+3 K_{0}, \\
a_{22}=(\lambda+2 \mu)\left(1+\frac{C}{4 \mu}\right)+b, \\
a_{23}=-2 \lambda\left(1+\frac{C}{4 \mu}\right)+b, \\
a_{31}=(\lambda+\mu)\left(1+\frac{C}{4 \mu}\right)+b+3 K_{0}, \\
a_{32}=b-2 \lambda\left(1+\frac{C}{4 \mu}\right), \\
a_{33}=(\lambda+\mu)\left(1+\frac{C}{4 \mu}\right)+b, \\
b_{1}=3 K_{0} \mu(\lambda+2 \mu)\left(\frac{C_{l x 1}^{2}}{C_{l 0}^{2}}-1\right), \\
b_{2}=3 K_{0} \mu\left(\frac{C_{s x 1}^{2}}{C_{s 0}^{2}}-1\right),
\end{gathered}
$$


lithology $1 \bullet$ lithology $2 \bullet \operatorname{lithology} 3$

- lithology 4 - lithology 5

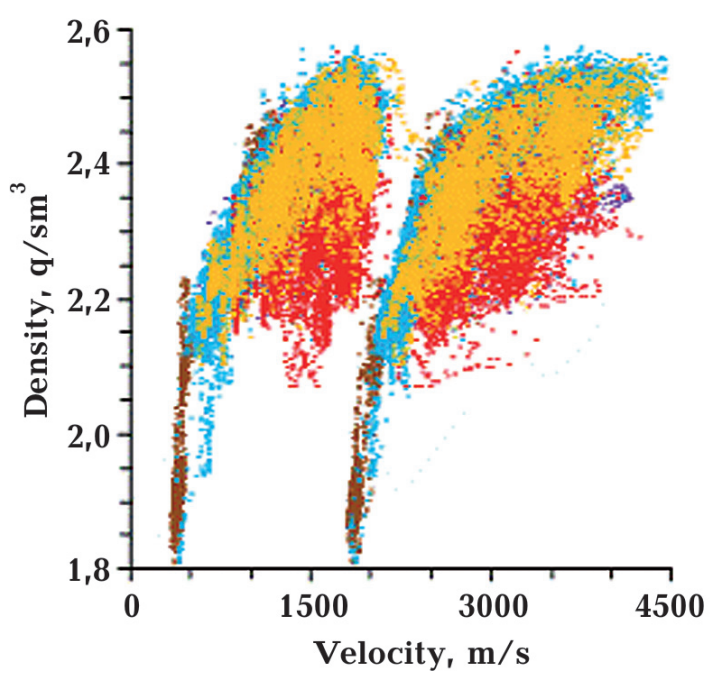

Fig. 1. Dependencies of velocities of pressure and shear waves on density of rocks of various lithology. Well 1.

Fig. 2. Correlations of velocity of pressure and shear $\Leftrightarrow$ waves on geostatic pressure on rocks of different lithology. Well 1. Colors lithologies are shown in Fig. 1.

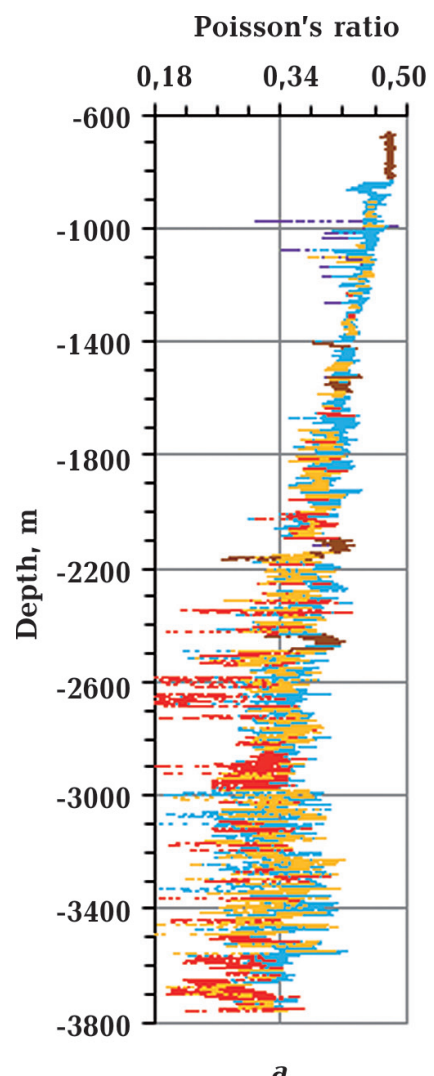

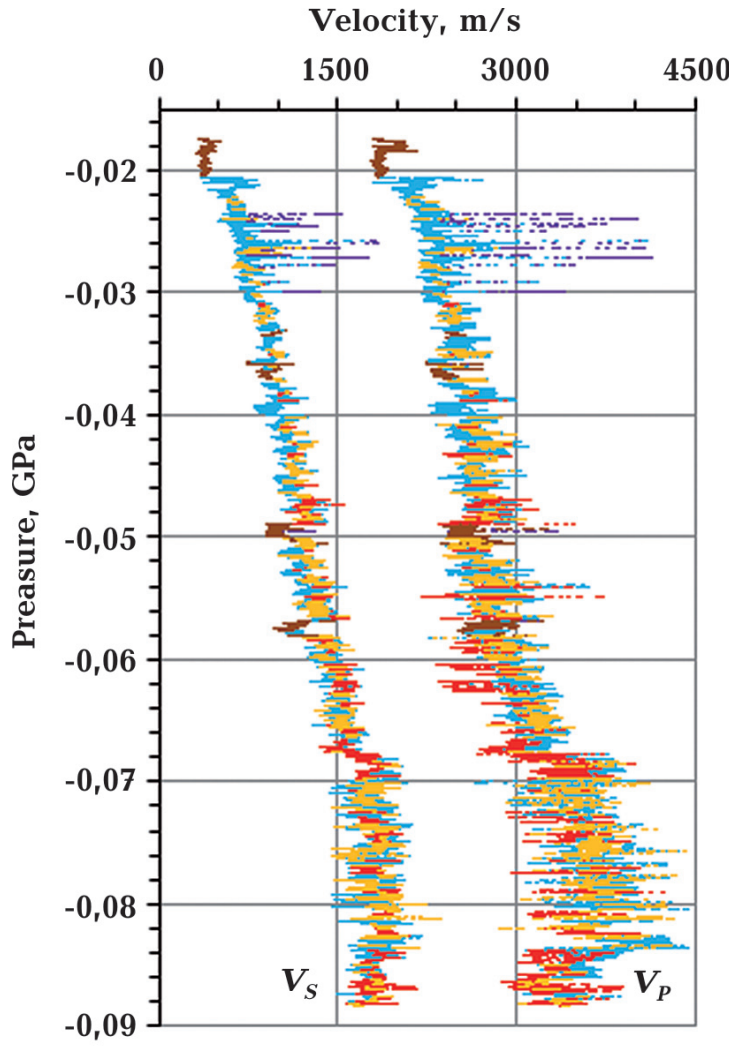

Module $b$, GPa
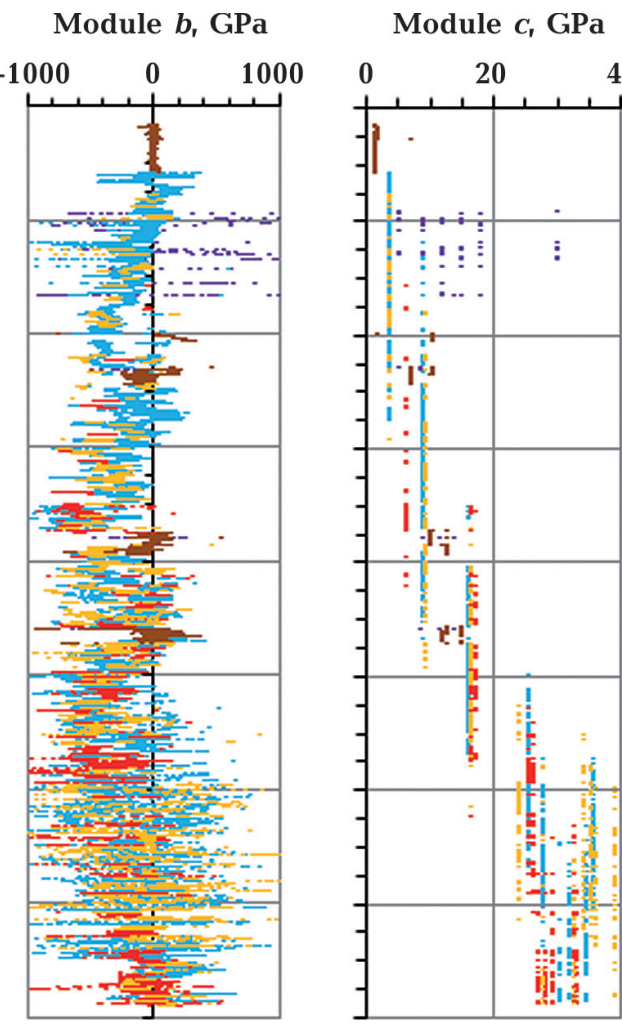

C

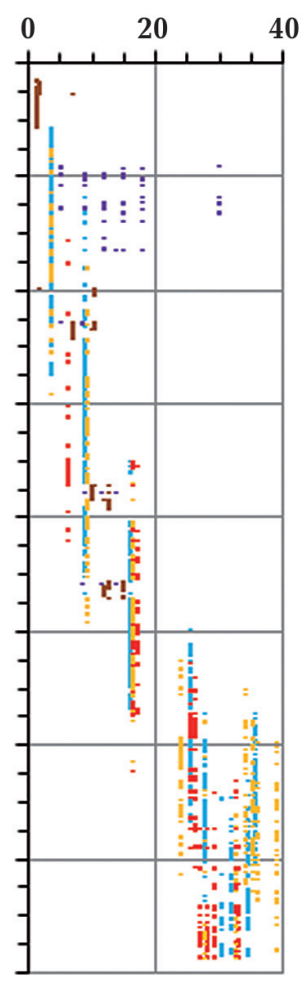

$d$

Fig. 3. Distribution of values of Poisson's ratio depending on the depth of different rocks of the medium according to well 1 logging data. Colors lithologies are shown in Fig. 1. 

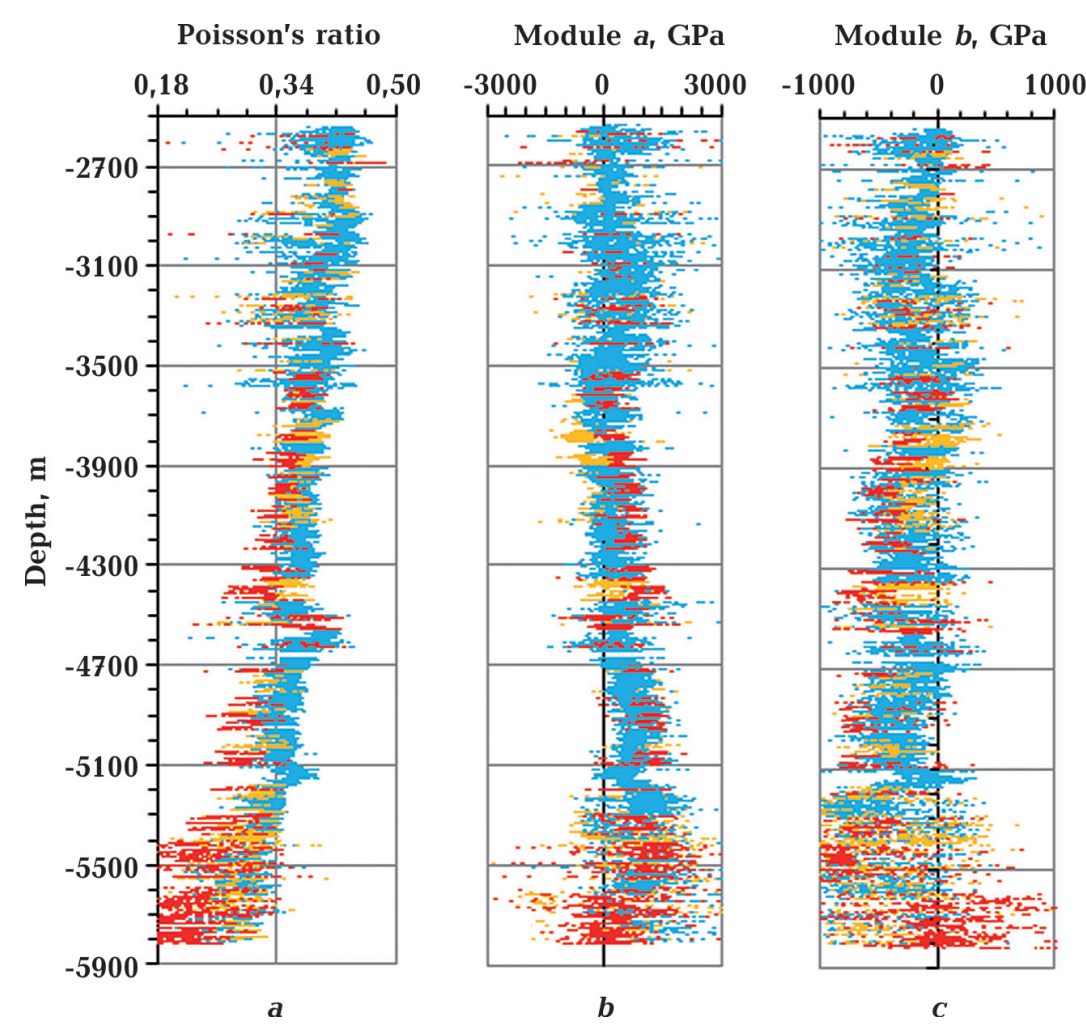

Module $c_{\text {, }}$ GPa
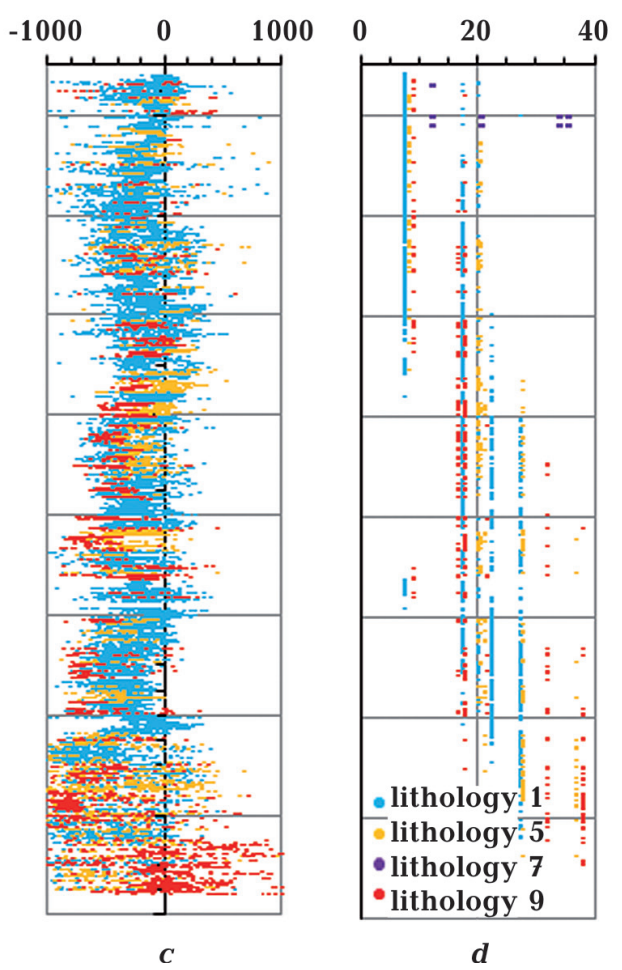

Fig. 4. Distribution of values of Poisson's ratio depending on the depth of different rocks of the medium according to well 2 logging data.

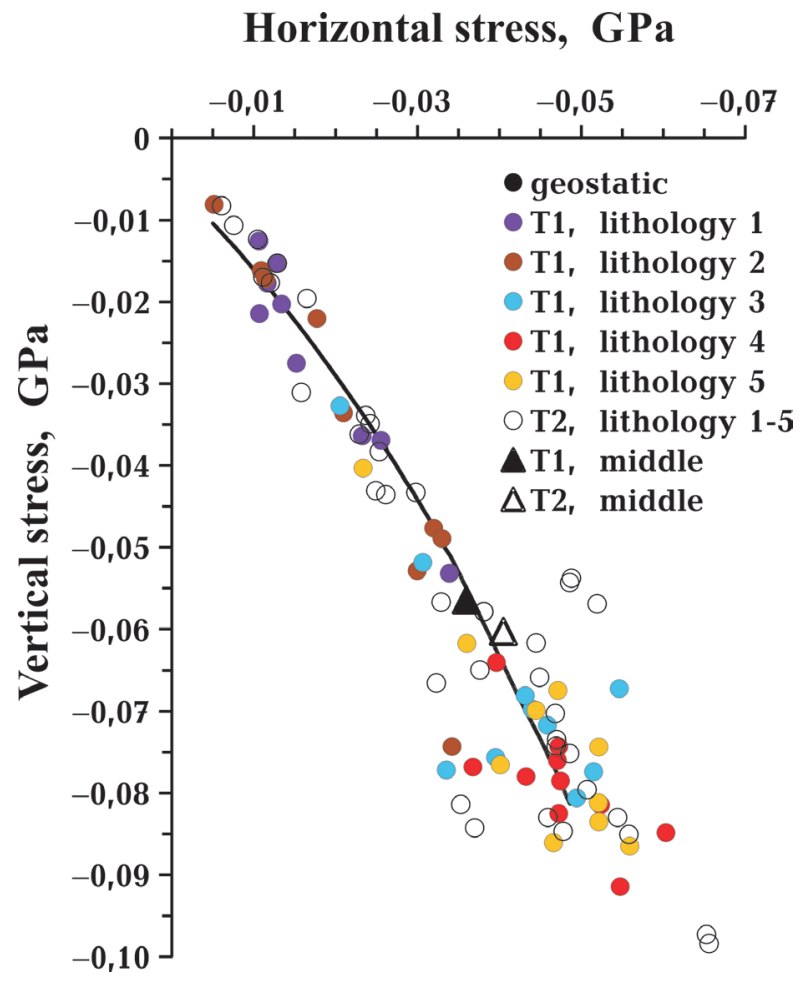

Fig. 5. Correlations between normal components of stress tensor on well 1.

\section{Horizontal stress, GPa}

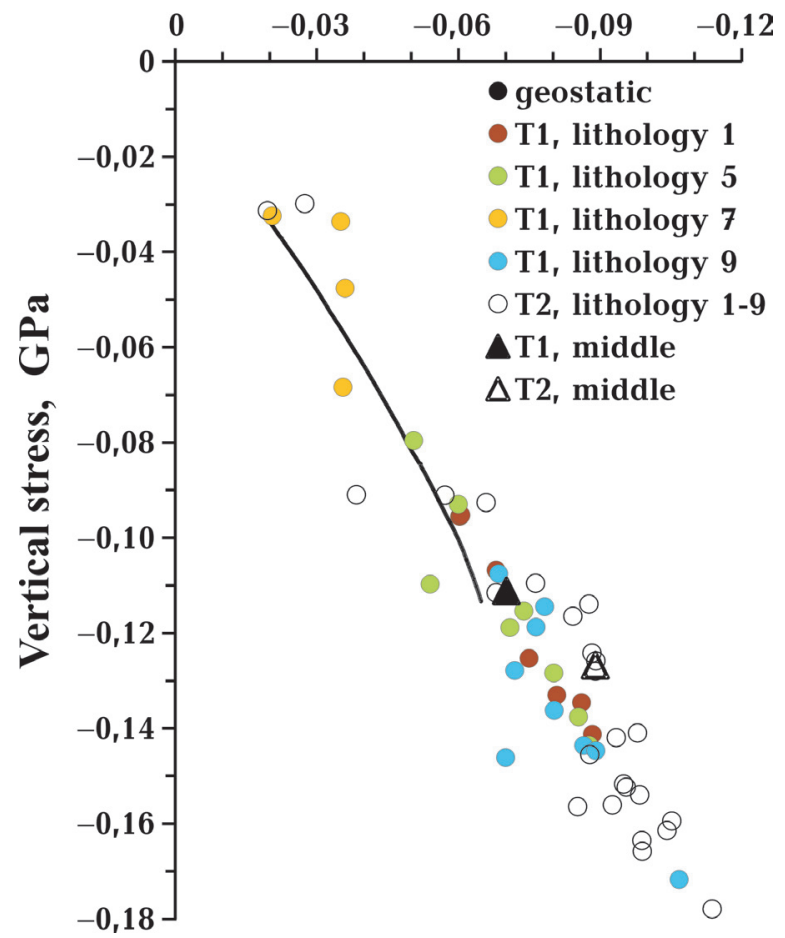

Fig. 6. Correlations between normal components of stress tensor on well 2. 


$$
b_{3}=3 K_{0} \mu\left(\frac{C_{s x 3}^{2}}{C_{s 0}^{2}}-1\right),
$$

where $K_{0}, \lambda, \mu$ - elasticity moduli of the second order; $a, b, c$ - elasticity moduli of the third order in the deformed $(\mathrm{P} \neq 0)$ medium; $C_{l x 1}, C_{s x 2}, C_{s x 3}$ - velocities of pressure $S H$ and SVtypes of shear waves accordingly propagating along the axis $l x 1, s x 2$ and $s \times 3$ in the deformed medium $(\mathrm{P} \neq 0) ; C_{l 0}$ - pressure velocity, $C_{S}$ - velocities of $S H$ and $S V$ types of shear waves in the undeformed $(\mathrm{P} \neq 0)$ medium, accordingly.

Directions of axes in the medium are: $l x 1$ (Z-vertical), lx2 (X-horizontal), lx3 (Y-horizontal).

The elements are determined according to the following correlations in case of the second version of the theory of small initial deformations [Guz, 2004]:

$$
\begin{gathered}
a_{11}=2(\lambda+\mu)(\lambda+2 \mu+2 b+c)+ \\
+2(a+b) \mu+3 K_{0} \mu, \\
a_{12}=2(a+b) \mu-\lambda(\lambda+2 \mu+2 b+c), \\
a_{13}=2(a+b) \mu-\lambda(\lambda+2 \mu+2 b+c), \\
a_{21}=2(\lambda+\mu) \frac{C}{4 \mu}(\lambda+2 \mu)+b+3 K_{0}, \\
a_{22}=-\lambda+\frac{C}{4 \mu}(\lambda+2 \mu)+b, \\
a_{23}=-\lambda-\frac{\lambda C}{\mu}+b, \\
a_{31}=2(\lambda+\mu)+\frac{(\lambda+2 \mu) C}{4 \mu}+b+3 K_{0}, \\
a_{32}=-\lambda-\frac{C \lambda}{\mu}+b, \\
a_{33}=-\lambda+\frac{C(\lambda+2 \mu)}{4 \mu}+b .
\end{gathered}
$$

It's possible to obtain calculation formulae similar to (4) and (5) while using «natural» velocities based on the acoustoelastic correlations [Guz, 2004].

Numerical results and discussion. The data given in Fig. 5 and Fig. 6. are separately averaged to obtain values of elasticity moduli on the entire well. At the same time, the num- ber of medium layers for each data cluster is used as weights using the same lithology of rocks. The number of medium layers for each rock is used as weights while averaging the results for all rocks. The obtained values of elasticity moduli on the entire well are given in Table 1 and Tab. 2. The numerators contain the results related to the first version of the theory of small and the theory of large initial deformation. Forms of elastic oscillations are modeled considering «true» velocities. The results obtained within the second version of the theory of small initial deformation are given in denominators in Tab. 1.

The results of the calculation of normal components of stress tensor are given in Table 2 . The last columns contain the results of calculating the Lode-Nadai coefficient [Gintov, 2005; Gzovsky, 1975].

Simple analytical expressions are obtained to calculate the principal components of the stress tensor in the geological medium using the Lagrangian method of describing its nonlinear deformation.

The results given in Table 2 show that the calculated values of the normal components of the stress tensor don't differ qualitatively within the various versions of the theories of initial deformation. In this case, all the normal components of the stress tensor are compressive. The values of the stress within the second version of the theory of small initial strains are larger than similar values to the theory of large initial deformation.

The studied medium has a complex geological structure and a thermobaric state. There is a high-amplitude anticline structure and thick layers with anomalous high plastic pressure. The rocks of separate layers are saturated with oil and gas [Babayev, Gadzhiev, 2006].

A comparative analysis is carried out to determine the reliability of the obtained results. The correlations between the stress components are studied. The results of this manuscript (points on the graph) and the results of the standard calculation of stress components (continuum line) caused only by geostatic pressure are used [Gintov, 2005].

The correlation between $\sigma_{11}^{0}$ and $\sigma_{22}^{0}$ is shown according to well data in Fig. 5. The 
Ta b l e 1 . Numerical values of elasticity moduli

\begin{tabular}{|c|c|c|c|c|c|}
\hline Well number & $\mu, \mathrm{GPa}$ & $\lambda, \mathrm{GPa}$ & $a, \mathrm{GPa}$ & $b, \mathrm{GPa}$ & $c, \mathrm{GPa}$ \\
\hline 1 & $\frac{4,249}{4,249}$ & $\frac{11,509}{11,509}$ & $\frac{372,609}{307,770}$ & $\frac{-188,713}{-144,122}$ & $\frac{14,945}{-39,890}$ \\
\hline 2 & $\underline{6,532}$ & $\underline{14,847}$ & $\underline{401,953}$ & $\frac{-266,311}{3,532}$ & $\frac{21,655}{-206,465}$ \\
\hline
\end{tabular}

Ta b l e 2. The numerical values of the normal components of the stress tensor in case of using the elastic potential of the Murnaghan type

\begin{tabular}{|c|c|c|c|c|}
\hline $\begin{array}{c}\text { Well } \\
\text { number }\end{array}$ & $\sigma_{11}^{0}, \mathrm{GPa}$ & $\sigma_{22}^{0}, \mathrm{GPa}$ & $\sigma_{33}^{0}, \mathrm{GPa}$ & $\begin{array}{c}\text { Lode-Nadai } \\
\text { coefficient }\end{array}$ \\
\hline 1 & $\frac{-0,05655}{-0,06603}$ & $\frac{-0,03597}{-0,03597}$ & $\frac{-0,03597}{-0,03597}$ & $\frac{-1,000000}{-1,000000}$ \\
\hline 2 & $\frac{-0,11123}{-0,12677}$ & $\frac{-0,07026}{-0,08905}$ & $\frac{-0,07026}{-0,08905}$ & $\frac{-1,000003}{-1,000000}$ \\
\hline
\end{tabular}

graphs of correlations are constructed on each lithology of rocks for the cases of the first version of the theory of small and large initial (T1) and the second vaersion of the theory of small initial (T2) deformation. It follows from the graph that as the values $\sigma_{11}^{0}$ and $\sigma_{22}^{0}$ increase, their dispersion also increases. It is explained by the fact that the rocks lying in the deep layers are in more complex stress states. The (middle) values $\sigma_{11}^{0}$ and $\sigma_{22}^{0}$ averaged on 5 types of lithology of rocks are given.

The continuum line approximates the numerical data of correlations between $\sigma_{11}^{0}$ and $\sigma_{22}^{0}$ well. It means that the proposed method allows obtaining reliable results.

The highest values of stress components caused by geostatic pressure $(-0,0486$ and $-0,0813 \mathrm{GPa})$ are significantly lower than the calculated values on $\sigma_{11}^{0}$ and $\sigma_{22}^{0}(-0,0656$ and $-0,0984$ GPa) (see Fig. 5). It shows that there are other causes of stress occurrence in addition to forces of geostatic pressure in the geological medium.
Similar results have also been obtained on data of well 2 (see Fig. 6). The rocks of the same stratigraphic complex are in significantly higher temperature and pressure conditions than in well 1 . Therefore, the values $\sigma_{11}^{0}$ and $\sigma_{22}^{0}$ differ even more from geostatic pressure according to well data. As intensive geodynamic processes of a local and regional character take place in the studied sedimentary cover of 25-30 km capacity. Diapiric and anticlinal structures have been developed. The occurred dynamic processes appear in the form of frequent earthquakes and eruptions of mud volcanoes.

Thus, the proposed method allows reliably determining normal components of stress state in the geological medium considering modern geodynamic variability.

Acknowledgements. The research described in this manuscript has been financed by the Natural Science Foundation grant project of the Ukrainian Scientific and Technological Center \#6284.

\title{
Determination of stress in the geological medium on the basis of well data using acoustoelastic correlations
}

\author{
H. H. Guliyev, K. B. Aghayev, G. A. Sultanova, 2019
}

A method has been developed to determine normal components of the stress tensor in deformed geological media on the basis of geophysical deep well logging. The theoretical 
basis of the method is the acoustic correlations of the non-classical linearized approach of nonlinear elastodynamics. Analytical formulae are obtained to calculate the stress in the geological medium in cases of small and large deformations. Geophysical well logging data located in the South Caspian basin have been used. Thin-layered one-dimensional models of the medium have been compiled on velocities of pressure and shear waves, density and lithology of rocks. The thickness of each layer of the model is several centimeters, which is equal to the observations in the well. The data of each model related to the same rock lithology is divided into clusters using artificial neural networks to consider the influence of changes of thermobaric conditions of the geological medium on acoustic properties of rocks. Values of elasticity moduli of the second and third orders and components of normal stress tensor have been calculated according to models for each lithology of rocks and a cluster of data. It has been revealed that elasticity moduli of the third order are much more sensitive to the variability of elastic properties of the medium than moduli of the second order. The obtained numerical results on all clusters of each lithology of rocks are averaged. At the same time, the number of medium layers on each data cluster has been used as weights. The number of medium layers in each rock has been used as weights while averaging the results for all the rocks. The correlations between numerical values of normal components of stress tensor caused by geostatic pressure and similar values caused by geodynamic changes of stress tensor have been studied. It has been revealed that values of stress bulk caused by geostatic pressure are significantly lower than stress caused by geodynamic changes. The obtained acoustic formulae allow determining values of stress in the geological medium of any region considering the influence of modern geodynamic processes.

Key words: acoustic correlations, stress, elasticity moduli, geophysical well logging, data cluster.

\section{References}

Abasov, M. T., Guliyev, H. H., \& Dzhevanshir, R. D. (2000). The model of lithosphere development. Vestnik RAN, 70(2), 129-135 (in Russian).

Aghayeva, S. T., \& Babayev, G. R. (2008). Analysis of earthquake foci of large and small Caucasus according to the method of constructing a world stress map. In Catalogue of seismoforecasting research carried out in Azerbaijan territory (pp. 51-55). Baku (in Russian).

Akbarov, S. D. (2015). Dynamics of Pre-Strained Bi-Material Elastic Systems: Linearized ThreeDimensional Approach. Springer-Heildelberg, Newswork, 1003 p.

Alexandrov, K. S., Prodaivoda, G. T., \& Maslov, B. P. (2001). Method of determination of nonlinear elastic properties of rocks. Doklady RAN, 380(1), 109-112 (in Russian).

Anderson, D. (2007). New Theory of the Earth. Cambridge University Press, New York, USA. 385 p.

Babaev, D. Kh., \& Gadzhiev, A. N. (2006). Deep structure and oil and gas potential of the Caspian Sea basin. Baku: Nafta-Press, 305 p. (in Russian).
Bakulin, V. N., \& Protoseniya, A. G. (1982). The presence of nonlinear effects during the propagation of elastic waves in rocks. Doklady AN SSSR, 263 (2), 314-316 (in Russian).

Balakina, L. M., Vvedenskaya, A. V., Golubeva, N. V., Misharina, L. A., \& Shirokova, E. I. (1972). Field of the Earth's elastic stresses and the mechanism of earthquake sources. Moscow: Nauka, 191 p. (in Russian).

Bayuk, E. I., Tomashevskaya, I. S., \& Dobrynin, V. M. (1988). Physical properties of minerals and rocks within high thermodynamic parameters: Handbook. Moscow: Nedra, 255 p. (in Russian).

Biot, M. A. (1965). Mechanics of incremental deformations. Ph.D. Dissertation. New York: Wiley, $560 \mathrm{p}$.

Garotta, R. (2000). Transverse waves: from registration to interpretation. Short course of lectures for higher educational institutions. The publication of the American Society of Exploration Geophysicists (SEG), 221 p. (in Russian)

Chashkov, A. V., \& Valery, V. M. (2011). Use of the cluster analysis and artificial neural network 
technology for log data interpretation. Zhurnal Sibirskogo federalnogo universiteta. Tekhnika i tekhnologiya, 4(4), 453- 462 (in Russian).

Gintov, O. B. (2005). Field tectonophysics and its application in the study of deformation of the Earth's crust. Kiev: Feniks, 572 p. (in Russian).

Guliyev, H. H. (2000). Determination of Poisson's ratio in the strained medi. Doklady AN, 370(4), 534-537 (in Russian).

Guliyev, H. H. (2018a). Geomechanical analysis of elastic parameters of the solid core of the Earth. Geomechanics and Engineering, 14(1), 19-27. https://doi.org/10.12989/gae.2018.14.1.019.

Guliyev, H. H. (2018b). On the elastic parameters of the strained media. Structural Engineering and Mechanics, 67(1), 53-67. https://doi. org/10/12989/sem2018.67.1.053.

Guliyev, H. H., \& Aghayev, Kh. B. (2011). Determination of physicomechanical properties of sedimentary cover rocks on the basis of seismic, borehole data and the theory of elastic waves of stressed media. Geofizicheskiy zhurnal, 33(6), 126-135. https://doi.org/10.24028/ gzh.0203-3100.v33i6.2011.116798 (in Russian).

Guliyev, H. H., Aghayev, Kh. B., \& Hasanova, G. H. (2016). Determining the Elastic Moduli of the Third Order for Sedimentary Rocks Based on Well-Logging Data. Izvestiya, Physics of the Solid Earth, 52(6), 836 - 843. doi: 10.1134/ S1069351316050062.

Guliyev, H. H., \& Dzhabbarov, M. D. (1998). The propagation of elastic waves in the strained anisotropic media. Doklady Akademii nauk Azerbaydzhanskoy SSR, (2), 103-112 (in Russian).

Guliyev, H. H., Javanshir, R. J., \& Hasanova, G. H. (2018). Determination of elastic parameters of the deformable solid bodies with respect to the Earth model. Geomechanics and Engineering, 15(5), 1071-1080. https://doi.org/10.12989/ gae.2018.14.1.019.

Guz, A. N. (2004). Elastic Waves in Bodies with Initial (Residual) Stresses. Kiev: A.S.K., 672 p. (in Russian).

Guz, A. N., Makhort, F. G., Gushcha, O. I., \& Lebedev, V. K. (1974). Fundamentals of the ultrasonic non-destructive method for the determination of stress in solids. Kiev: Naukova Dumka, 106 p. (in Russian).
Gzovsky, M. V. (1975). Fundamentals of Tectonophysics. Moscow: Nauka, 536 p. (in Russian).

Heidbach, O., Barth, A., Connolly, P., Fuchs, K., Müller, B., Tingay, M., Reinecker, J., Sperner, B., \& Wenzel, F. (2004). Stress maps in a minute: the 2004 World Stress Map release. EOS Trans, 85(49), 521-529. https://doi. org/10.1029/2004EO490001.

Li, X. \& Tao, M. (2015). The influence of initial stress on wave propagation and dynamic elastic coefficients. Geomechanics and Engineering, 8(3), 377-390. https://doi.org/10.12989/ gae.2015.8.3.377.

Müller, B., Barth, A., Heidbach, O., Reinecker, J., Sperner, B., Tingay, M., \& Wenzel, F. (2005). The World Stress Map-an essential and easy accessible tool for geohazard assessment. International Workshop Recent Geodynamics, Georisk and Sustainable Development in the Black Sea to Caspian Region, Baku, AIP, 825, 19-31.

Poulton, M. M. (2002). Neural networks as an intelligence amplification tool: A review of applications. Geophysics, 67(3), 979-993. https:// doi.org/10.1190/1.1484539.

Reinecker, J., Heidbach, O., \& Müller, B. (2005). The 2005 release of the World Stress Map. Retrieved from www.world-stress-map-org.

Teachavorasinskun, S., \& $V_{S}$ Pongvithayapanu, P. (2016). Shear wave velocity of sands subject to large strain triaxial loading. Geomechanics and Engineering, 11(5), 713-723. https://doi. org/10.12989/gae.2016.11.5.713.

Tromp, J., Marcondes, M. L., Wentzcovitch, R., \& Trampert, J. (2019). Effects of Induced Stress on Seismic Waves: Validation Based on Ab Initio Calculations. Journal of Geophysical Research: Solid Earth, 124(1), 729-741. https:// doi.org/10.1029/2018JB016778.

Vyzhva, S. A., Maslov, B. P., \& Prodaivoda, G. T. (2005). Effective elastic properties of nonlinear multicomponent geological media. Geofiziches kiy zhurnal, 27(6), 1012-1022 (in Russian).

Yin, H., \& Rasolofosaon, P. (1994). Nonlinear and linear elastic behavior of anisotropic rocks: Ultrasonic experiments versus Theoretical predictions. Abstract, 64 SEG meeting, Los Angeles, Expanded Abstract, paper SL3.4, 1129-1132. 